Comparative Philosophy Volume 1, No. 2 (2010): 3-23

Open Access / ISSN 2151-6014

www.comparativephilosophy.org

\title{
THE LABYRINTH OF PHILOSOPHY IN ISLAM
}

\author{
NADER EL-BIZRI
}

\begin{abstract}
This paper focuses on the methodological issues related to the obstacles and potential horizons of approaching the philosophical traditions in Islam from the standpoint of comparative studies in philosophy, while also presenting selected casestudies that may potentially illustrate some of the possibilities of renewing the impetus of a philosophical thought that is inspired by Islamic intellectual history. This line of inquiry is divided into two parts: the first deals with questions of methodology, and the second focuses on ontology and phenomenology of perception, by way of offering pathways in investigating the history of philosophical and scientific ideas in Islam from the viewpoint of contemporary debates in philosophy. A special emphasis will be placed on: (a) interpreting the ontology of the eleventh century metaphysician Ibn Sinā (known in Latin as: Avicenna; d. 1037 CE) in terms of rethinking Heidegger's critique of the history of metaphysics, and (b) analyzing the philosophical implications of the theory of vision of the eleventh century polymath Ibn al-Haytham (known in Latin as Alhazen; d. ca. 1041 $C E)$ in terms of reflecting on Merleau-Ponty's phenomenology of perception.
\end{abstract}

Keywords: being, epistemology, Martin Heidegger, Ibn al-Haytham (Alhazen), Ibn Sinā (Avicenna), Maurice Merleau-Ponty, ontology, optics, perception, phenomenology, philosophy (Islam), science (Islam)

\section{PART I}

\section{LINGUISTIC POINTERS AND CONCEPTUAL DIRECTIVES}

The expression, 'Islamic philosophy', as it is rendered in the English language, or in associated European idioms ('philosophie islamique'), refers in its technical linguistic sense to what is known in the original Arabic language as ' $\mathrm{falsafa}$ '. The term was historically coined in Arabic to adapt to the use of the Greek designation, 'philosophia', within classical Islamic intellectual traditions. The English appellation, 'Islamic philosophy', would be literally translated back into the Arabic language as, 'al-falsafa al-islämiyya', which points to a relatively modern usage of this expression in the context of referring to Islamic philosophical thinking in general terms. Consequently, 'al-falsafa al-islämiyya' may broadly refer to thought as it is inspired by Islam, and it would thus surpass the limits of the more clearly defined historical determination of the philosophical

EL-BIZRI, NADER: Affiliated Research Scholar, Department of History and Philosophy of Science, University of Cambridge, UK. Email: nebizri@aol.com 
legacy in Islam as falsafa per se. Accordingly, 'al-falsafa al-islämiyya' would include, in casual idiomatic usages, Islamic intellectual traditions that are not purely philosophical, but may be associated also with the Muslim schools of kalām (dialectical systemic theology) and of irfān (traditional monotheistic mysticism and gnosis), or even of tasawwuf (Sufism). The term, 'falsafa', in its classical and more specific technical sense, refers to a family of traditions in philosophy per se which gave expression to adapted assimilations, critical interpretations, and innovative expansions of Greek Peripatetic, Platonist, NeoPlatonist, and Neo-Pythagorean schools of thought within a diverse Muslim cultural milieu. The appellation 'falsafa' would have sufficiently designated a movement in philosophical thinking that is connected with Islam as a religion and civilization without the need to affirm that it was Islamic (islämiyya). The ambivalent use of the designator, 'falsafa', in relatively modern terms, would moreover encompass what some mystically-oriented Muslim scholars would take to be a way of life that rests on meditative spiritual exercises (al-riyādāt alrūhiyya) which aim at perfecting the self (what in Arabic is designated by the term 'al-nafs' [literally: 'the soul']) and refining its faculties in the hope of attaining wisdom, justice, happiness, and potentially aiming at the disclosure of the ultimate principles of reality which are taken to be veiled. ${ }^{1}$ In broad terms, falsafa generated isomorphic epistemic and ontological systems of thought which combined Greek legacies in philosophy with dynamic reflections on Abrahamic monotheism as a revealed religion while placing a particular emphasis on the multifarious interpretations of the religious teachings of Islam across diverse confessional expressions and denominations.

\section{COMPARATIVE INQUIRIES?}

It is perhaps insufficient to establish comparative studies in relation to classical texts and authors without taking certain precautionary methodological steps, which can be validated from the viewpoint of historiography, philology, paleography, and the distinction between traditions along the lines of historical and cultural differences, with their epistemic and ontological entailments. To avoid the conventional methodological strictures that are associated with the investigation of classics, perhaps it is more prudent if comparative inquiries are initially undertaken with respect to legacies that have well-documented historical and textual interconnections. In the case of the history of ideas in Islam, the focus would be directed toward the sequence of civilization and the linguisticconceptual transmission of knowledge from the Greek language into Arabic (at times via the agency of the Syriac language), and then from Arabic into Latin (occasionally via the agency of the Hebrew language). This procedure secures a context for the comparative historical study of texts and their intercultural adaptations within interlinked intellectual traditions. Accordingly, it would not be

\footnotetext{
1 In general, mystics in Islam (al-'urrāf or al-'ārifūn) focus on meditations, contemplations, fasting, spiritual exercises (al-riyādāt al-rūhīyya), and ritualistic forms of worship and prayer in view of connecting with what they consider to be the order of divinity while also aiming at the disclosure of the principles of reality, which they believe to be veiled (mahjüb) and can only be unveiled (kashf) via spirituality (rūhānīyyāt), instead of rationalistic deliberation and logical proof.
} 
controversial if comparative inquiries focus on the reception and response to the philosophical legacy of Ibn Sīnā (Avicenna) or Ibn Rushd (Averroes) by St. Thomas Aquinas or the European scholastics. The same can be said about the investigation of the assimilation of the scientific oeuvre of al-Hasan ibn alHaytham (Alhazen) by thirteenth century Franciscan scholars of optics (like Roger Bacon or Witelo). Such inquiries are considered acceptable from the standpoint of textual analysis, historiography, philology, paleography, and the history of science and philosophy. However, the conceptual and methodological elements become more complex and ambivalent, or, even doubted by some classicists, historians of ideas, philologists, or mediaevalists, when the analysis is undertaken from the viewpoint of contemporary debates in philosophy. This issue becomes further complicated, and confronted with greater opposition, when falsafa is examined from the standpoint of contemporary approaches in epistemology, ontology, or critical theory. This is principally due to the manner in which falsafa is studied in mainstream modern academia, namely, by being posited as an historical tradition that is surpassed and disconnected from modern thought. This mode of picturing falsafa is dominant in scholarship on Islamic philosophy despite its traces still constituting a living intellectual movement that is practiced, albeit, mimetically or in reproductive terms, within selected religious Islamic seminaries; this is the case particularly in Iran, and, up until the beginnings of the twentieth century, in places like the Azhar academy in Cairo. ${ }^{2}$ The investigation of falsafa, as an historical legacy, within the curricula of mainstream European-American academia, embodies an archaeological bent on studying philosophy in relation to Islam. This academic penchant regulates the methodology of the guardians of archival documentation. The historian of ideas studies the intellectual history of Islam in the spirit of an antiquarian compiler of knowledge who reports the textual material, and endeavors to document it, in order to primarily serve the establishment of library references. The aims and objectives of such learned exegetes and custodians of archiving, differ from the purposes of philosophers per se, who focus on the evolution of concepts and on the questions of ontology, epistemology, logic, value theory, etc.

The methodologies of historiography, philology, and paleography, in the analysis of texts and the archival tracing of their channels of transmission, aim principally at establishing textual documents. This approach has been historically shaped by the development of classicist and mediaevalist methods of studying Greek and Latin texts, ultimately affecting the investigation of Islamic textual sources, given that most scholars in the academic field of Islamic Studies in Europe and North America were, until recently, closely connected in pedagogic and methodological terms with the broader area of Oriental Studies. Scholarship in Islamic Studies within European and American academia was guided by the narrow trajectories of Orientalism. While it is historically evident that the

${ }^{2}$ The mimetic reproduction of past philosophical traditions in contemporary Muslim religious circles takes into account some of the pressing lived problems of socio-politics, ethics, and the applications of the religious law while being based on traditionalist ontological and epistemological foundations that have not been radically reformed since pre-modern times. One poignant example that presents itself in this regard is embodied in an implicit presupposition of a pre-Keplerian cosmology when reflecting on the questions of metaphysics (al-ilāhìyyät) in relation to Islam. 
orientalists facilitated the retrieval of non-European intellectual textual legacies, and also assisted in situating them in their historical and cultural contexts, their studies were nonetheless generally marked by ideological and colonialist perspectives that still require corrective reforms in terms of rewriting many chapters in the history of philosophy and science. After all, the question concerning the distortive implications of Orientalism in scholarship and culture is still controversial and remains fervently debated. We are intellectually indebted to the reflections of Edward Said in this regard who ushered a new critical attitude toward Oriental Studies, and challenged the unquestioned complacencies in representing the Orient through the ideological prisms of Orientalism, which served, until recently, the European colonial material interests (Said, 1978). ${ }^{3}$

Besides these aforementioned obstacles, additional difficulties arise due to the manner by which pre-seventeenth century history of science and philosophy is generally removed from the central debates in contemporary philosophical thinking. After all, philosophers feel less restricted studying figures like Descartes, Leibniz, Newton, Kant or Hegel, than they do when dealing with thinkers from epochs earlier than the seventeenth century or the high Renaissance. Exceptions do emerge, such as with studies in Neo-Thomism, or the analysis of Aristotelian doctrines in relation to contemporary questions in the philosophy of mind, but these remain marginal with regard to the current central topics of philosophizing per se. Furthermore, while considering the contributions of philosophers of the Islamic civilization (al-faläsifa) within the mainstream philosophy department curricula (especially in non-Muslim contexts), these are usually concealed within the deep folds of mediaeval European thought. Islamic philosophy is rarely investigated from perspectives that are not strictly confined within mediaevalist studies. The academic value of the philosophers of Islam is usually measured in philosophical scales according to how they facilitate the pedagogic and intellectual understanding of European scholasticism, the mediaeval interpretation of the Greek corpus in general, and the Aristotelian tradition in particular.

\section{IMPASSES OR HORIZONS?}

Studying the impetus of philosophizing in relation to Islam, as a faith and civilization, from a contemporary standpoint in philosophical thinking remains a desideratum that points to diverse obstacles, which can be summarized as follows: 1. Historical (since falsafa is principally posited as being mediaeval); 2. Cultural (by assuming that falsafa is incommensurably oriental); 3. Textual-archival (that falsafa was transmitted in fragments to the European context and its intellectual influence within philosophy gradually decreased and disappeared); and 4. Islamicate (in the sense of resisting [prudently, dogmatically, or politically] what some Muslim scholars see as being a contamination of the traditionalist Islamic legacies with unnecessary and alien philosophical constructs that are derived from American/European sources). These methodological strictures, coupled with the

\footnotetext{
${ }^{3}$ European Orientalism had further prolongations within American discourses on the Orient in serving US foreign policies; these were also dialectically paralleled by historical materialist geopolitical approaches to integrating the Muslim communities within the Soviet Union.
} 
historicist angst regarding anachronism in historiography, can be surpassed through the careful steps of opening up the horizons of reflection on common questions in epistemology, ontology, logic, in addition to the assessment of responses to questions within the fields of philosophy of science, religion, and art. By way of illustrating the possibilities of such analytics, and in terms of pointing out some novel pathways for thinking, in spite of the conventional methodological strictures, the second part of this present paper offers two case-studies that investigate the potentials of renewing the philosophical engagement with the history of ideas in Islam. In this sense, I examine the ontology of Ibn Sinnā (Avicenna; d. $1037 \mathrm{CE}$ ) from the standpoint of Heidegger's critique of the history of metaphysics, ${ }^{4}$ and I reflect on the epistemic dimensions of the theory of vision of Ibn al-Haytham (Alhazen; d. ca. $1041 \mathrm{CE}$ ) from the viewpoint of MerleauPonty's phenomenology of perception.

\section{RENEWAL IN PHILOSOPHIZING?}

The present course of investigation in this paper aims at finding ways by which the impetus of philosophizing in relation to the history of ideas in Islam can be renewed. So, is it indeed possible to develop a new school of falsafa that is contemporary and retains various forms of epistemic, hermeneutic, and textual interconnections with intellectual history in Islam? In what ways would it also contribute to elucidating contemporary mainstream philosophical debates in relation to science, religion, technology, art, politics, ethics, society and culture?

Just like the early Islamic philosophers and theologians developed their intellectual traditions in response to their encounters with the Greek corpus, and by confronting the theoretical and practical challenges of their own epoch, new forms of falsafa can be shaped in connection with Islam and in direct philosophical engagements with modernity in its variegated forms. For instance, investigating Ibn Sīnā's ontology, from the standpoint of critically rethinking Heidegger's critique of the history of metaphysics, would not necessarily or readily result in the development of a novel way of philosophical thinking, as this initially took place in the case of al-Kindī's reading of the Neo-Platonized version of the Aristotelian corpus that was available to him in the ninth century. ${ }^{5}$ Nevertheless, this intellectual exercise might allow for a third pathway in thought to emerge that would revive some aspects of ontology in the history of ideas in

\footnotetext{
4 I initiated this specific line of ontological inquiry elsewhere (El-Bizri, 2000). The phenomenological investigation of selected philosophical traditions in Islam is also supported by a book-series that I co-edited with Anna-Teresa Tymieniecka (President, World Phenomenology Institute, Hanover, New Hampshire) and Gholam-Reza Aavani (Director, Iranian Institute of Philosophy, Tehran), which is entitled, Islamic Philosophy and Occidental Phenomenology in Dialogue (a series that is published by Springer [formerly, Kluwer Academic Publishers] in Dordrecht and Berlin).

5 The transmission and translation of manuscripts that were associated with the Aristotelian corpus, within the scholarly circles in Islamic civilization in the ninth century, resulted in the attribution of two texts to Aristotle, which were imbued with Neo-Platonized leitmotifs. The first text was the so-called Theology of Aristotle (in Arabic: al-Thīyūiujizyyā), and the second was the Book of Pure Goodness (in Arabic: Kitāb al-khayr al-mahd; in Latin as: Liber de Causis).
} 
Islam in a manner that actively engages with reflections on the question of being in our age and its techno-scientific bearings, while also being situated within the circles of contemporary philosophical deliberation and thinking. Similarly, an inquiry about Ibn al-Haytham's optics, from the viewpoint of the phenomenology of perception, can potentially open up new possibilities for reflections in epistemology, and approach the history of the exact sciences in Islam beyond the narrow confines of historiography per se.

\section{BREAKING THE MOLD?}

Current advancements in techno-science, the development of efficient and wide ranging capacities in telecommunications, and the technical as well as economic facilitation of travel and study abroad (along with the establishment of various branches of European and North-American universities in Asia and the Middle East) entice us to rethink inherited epistemic models of picturing the history of philosophy and science. The potentials of emancipation and the generation of novel schools of philosophy in this present century, by way of being inspired by intercultural intellectual histories, cannot be arrested or compromised in terms of succumbing to the restrictions imposed by the custodians of archives within the circles of classicists, mediaevalists, and orientalists. The dominance of Orientalism and Eurocentric models in understanding and studying Islamic philosophy is no longer sustainable, even if it is still deeply entrenched in the most established and oldest institutions of higher-education in Europe and NorthAmerica. Moreover, the construction of knowledge, its dissemination, adaptive reception, and interpretive assimilation through sequences of civilizations, and in cultural-political terms that modulate the sociology of philosophical and scientific knowledge, cannot be all contained by the rules of reportage and documentary archiving. The intellectual heritage of a people cannot simply be posited as relics from the past that can only be studied through the narrow channels of academic expertise in documenting traditions. This is especially the case if such heritage is still a living source of cultural inspiration for multiple communities, and partly shapes, in tacit forms, some of their inherited outlooks on the universe concerning truth, goodness, beauty, justice and governance. This is clearly the case with respect to the history of philosophical and scientific ideas in Islam which reflects on socio-cultural dimensions that classicists, mediaevalists, and scholars of Oriental Studies are unable to fully acknowledge or recognize. This state of affairs reveals the need to be more directly engaged in critically analyzing these past legacies from the viewpoint of the potential connection of their fundamental elements with contemporary concerns in thinking. Greater possibilities are now available for studying the classics through developments in narrative analysis, critical theory, post-modernist discourse, the technicalities of epistemology and logic in the Analytic School in philosophy, along with the unfolding of the horizons of fundamental ontology, hermeneutics, phenomenology, and deconstruction. All offer enriching differential potentials for the renewal of philosophical inquiry, cultural dialogue, and intellectual exchanges across civilizations. Having stated that, it remains indeed essential to rely at times on philology, paleographic textual analysis, the critical editing of manuscripts, the 
production of annotated translations, and the establishment of exegetical commentaries, which are based on sound historiography, all in order to render the classical sources accessible. Such noble aims may be sufficient from the viewpoint of establishing the classical material on sound historical and textual grounds. However, from the perspectives that surpass the limits of these conventions, what are the epistemic, cognitive, and cultural entailments of the history of philosophy and science? And how do these inform contemporary debates in philosophy and their relationships with science, religion, art, politics, ethics, and culture? Do historical precedents have any implications with respect to inspiring, informing, or dialectically differing from our contemporary outlooks on the human condition, the cosmos, divinity, truth, goodness, beauty, and justice? Can they elucidate our grasp of the evolution of concepts and the taxonomies of knowledge and its canonization? Finally, what value do they bring to discussions regarding epistemology, ontology, logic, and value theory? These philosophical interrogations are customarily set outside the spheres of historiography, philology, paleography, and the archival documentation in the academic fields of Oriental and Islamic Studies.

\section{PREPARATORY STEPS IN COMPARATIVE INQUIRY}

In reflecting on the possibilities of renewing the impetus of philosophizing in relation to Islam, and thus in rekindling the potential reanimation of falsafa in contemporary terms, a measured prudence ought to be exercised. One's own voice as interpreter ought to be clearly distinguished from that of the original author of a historical text in order to show with lucidity where deviations and new propositions are presented, which belong to the spheres of critical analytics and hermeneutics, instead of being part of the textually-oriented practice of exegesis and documentation. This state of affairs doubles the interpretive activity to ensure that the classical text is soundly situated in its appropriate context in terms of its documented interconnections with other constellations of texts and pathways of transmission across languages and intellectual traditions. This activity can be intertwined with analyses that lift some of the old propositions from their narrowly determined historical spheres, by way of assessing their potencies in generating renewed and innovative horizons for philosophical thinking. Such matters do not fall squarely within the professional academic domain of the career-oriented study of philosophy and its history, especially in relation to Islam. However, many scholars, academics, and philosophers find themselves personally torn between contemporary philosophy from one side (with its various branches, quarrels, and most prominent Analytic-Continental bifurcation) and the attractiveness of other intellectual traditions that do not belong to modern American-European philosophy. Hence, they find themselves situated in a region between philosophy per se (narrowly labeled as 'Western' or 'Occidental') and the intellectual heritage of non-European civilizations (Chinese, Indian, Islamic). The biographical and intimately personal becomes intricately interwoven with the conceptual and academic, in such a way that areas of specialization and concentration result in sets of publications and communications that address topics that seem to be incommensurable or incompatible. Philosophers who find 
themselves in such circumstances seem to deal with antinomies while mediating multiple intellectual loyalties. The individual scholar would have to modify themes, methodologies, and procedures of disseminating research in view of serving narrowly delimited spheres of study, which separate contemporary philosophy from the historical depositories of wisdom and knowledge in nonEuropean traditions. It therefore becomes an urgent call for thinking about this question by those who find themselves trapped in this gap between traditions. It is this space, as the liminal region of the in-between, that we are driven more pressingly to occupy within this current century. We therefore start with conversations, dialogues, exchanges at the margins, and through comparative studies. Eventually, the intensification of such intellectual activities may result in works of synthesis, isomorphic unification, and the merging of horizons which offer novel possibilities for thought and the renewal of philosophy. In this process, many thinkers will continue to adjust their intellective persona depending on academic readership and scholarly audience, along the lines of dividing disciplines and oscillations over fissures in their philosophical thought, while proceeding by way of leaps from one intellectual tradition to another.

\section{FALSAFA IN THIS CURRENT CENTURY?}

It is unclear whether the investigation of philosophy, in the shadows of the field of Islamic Studies, and under the specter of Oriental Studies, connects with contemporary philosophy beyond the domains of comparative analysis. Would falsafa emerge in novel forms in our current century, which render it a relevant school of contemporary thought? The implications of this question can extend further in terms of renewing the Chinese or Indian philosophical tradition in response to contemporary philosophy, modernity, techno-science, and the organization of the models of modern episteme and material culture. Yet, the question concerning falsafa remains at this stage more intimately connected with the standpoint of those inspired by the history of ideas in Islam and those who partake in contemporary debates in philosophy.

This set of philosophical interrogations on methods of inquiry that we have traversed so far is meant to act as a prolegomenon to future reflections on this matter, while building on previous attempts to address this question in the endeavor to rekindle the possibilities it may offer in its potential unfolding. Such aspirations have been situated hitherto at the margins of the academic procedures that separate Islamic Studies from philosophy per se within the university curriculum, due to the pedagogical and methodological directives that are professionally controlled by influential authoritative peers in academia. These concrete aspects of academic life, the cultivation of scholarship, the destining of individual apprentices on career-paths, and the educational shaping of the formative constitution and aggregation of young academics, all point to the actual practicalities of specializing in Islamic philosophy. To gain proper grounding, it is not sufficient to study in a philosophy department, particularly for those who are not native speakers (or have the linguistic competence of native speakers) of the Arabic language (namely, the lingua franca of classical Islamic civilization), or of the Persian or Turkish language (with emphasis on Ottoman, which is not a lived 
and practiced linguistic tradition anymore). Besides the need to acquire a solid, or at least, a good working-knowledge of Arabic and/or Persian (or in some cases, of Ottoman Turkish), the research student at advanced graduate studies must also have a firm grounding in the history of ideas in Islam. This curriculum of language, history, and culture is shaped by Middle Eastern Departments and Faculties of Oriental Studies. Added to this is the historical aspect of falsafa as it is principally studied in mainstream academia. This would thus further require grounding in historiography, philology, paleographic textual analysis, and the assessment of manuscripts, along with a specific bent on conducting research through tedious biographical-bibliographical instruments, which rely heavily on annotations, and on reporting relegated narratives, anecdotes, and chronicles of past historians, travelers, commentators, copyists of codices, compilers of compendia, glossators and scholiasts. Having passed through these academic curricula, the research student, or doctoral candidate, who desires specializing in Islamic philosophy, would have been already cultivated as a scholar of Islamic Studies and not as a philosopher per se. Those who are able to retain their interest in contemporary philosophy would then either do it at the margins of their work in Islamic Studies, or they would be affiliated with philosophy departments that offer courses on Islamic philosophy, without conducting the most advanced forms of closely studying texts in their original language. Consequently, students become commentators on the primary sources through the agency of secondary or tertiary literature, and they acquire the reputation of being non-experts in the field as their work is assessed by the established scholars in the field of Islamic Studies. The gap widens with time and career progression, and the opportunities to oscillate between disciplines become narrower and riskier. Hence, a movement from contemporary philosophy toward Islamic Studies in investigating falsafa (or moving the other way round) all appear again as a series of leaps. The picture becomes furthermore unhandsome when Ancient Greek and, at times, Latin, are posited as additional linguistic requirements in the formation of scholars who endeavor to study falsafa, especially when their prospective inquiries are expected to be conducted in a restricted domain of comparativeness from the viewpoint of mediaevalist research that focuses on the documented transmission of knowledge from Greek into Arabic and Arabic into Latin.

\section{THE BARRIERS OF CONTEMPORARY PHILOSOPHY}

Besides the obstacles that result from the methods of historiography, philology, and paleography (in the domains of Oriental and Islamic Studies), the divisions within contemporary philosophy enact additional epistemic and conceptual barriers in the face of comparative research. Engagement with the history of philosophy from a contemporary standpoint is principally conducted within the so-called 'Continental School' in terms of the manner in which it mediates some of its central investigations regarding its critical reinterpretation of the history of philosophical and scientific ideas. Numerous controversies arise within this contemporary movement in philosophizing. For instance, a focus on Heidegger's critique of the history of metaphysics, which is undertaken against the horizon of the unfolding of science and the essence of technology, is itself burdened by 
quarrels within the field of Heideggerian Studies and its reception by philosophers from other intellectual traditions: disputes arise over the interpretation of technical, Heideggerian terms, or with regard to the determination of the course of the development of Heidegger's thought, or the translation of Heidegger's edited German texts into English, French or Italian. Additional polemics emerge in terms of the political shadows that are recast in recurrent patterns over Heidegger's biography, or by way of the diverse forms of opposition that his thought continues to face from the Husserlian phenomenologists and the Analytic philosophers, along with controversies that arise in terms of reading his works through the writings of J.P. Sartre, J. Beaufret, J. Derrida, and E. Levinas.

These multiple barriers become higher and frequently established when we consider the interpretation of the history of philosophy through Heideggerian perspectives. Classicists, mediaevalists, phenomenologists, and analytic philosophers all raise various differential doubts regarding such undertakings. The entirety of such polemics become hypercritical when an attempt is made in interpreting the ontology of Ibn Sinna (Avicenna) from the standpoint of Heidegger's critique of the history of metaphysics despite the fact that Avicennism (al-Sinawizya) ${ }^{6}$ belongs to the history of European thought, at least in its Latinate scholasticism, along with the implicit impact it had on foundational figures in modern philosophy, such as Kant and Hegel. The conceptual circumstances are perhaps less harsh when focusing on the oeuvre of MerleauPonty. Nonetheless, reading the history of science from a phenomenological viewpoint is not without its epistemic and methodological obstacles. These take more severe expressions when the inquiry focuses on the scientific legacies of brilliant polymaths like Ibn al-Haytham (Alhazen), in spite of his direct influence on the history of science in Europe, and even on architectural and artistic practices within the perspectivae traditions from the twelfth century until the period of the high Renaissance (El-Bizri, 2009, 2010; Kemp, 1978, pp. 134-61; 1984, 1989; Lindberg, 1971, pp. 66-83; 1997, pp. 355-68). Albeit, one can still resort to elegant combinations of epistemology and the history of science in terms of conducting this line of analysis based on the deployed methods akin to historians like A. Koyré, and more probingly, by thinkers like G. Bachellard, in view of bridging the gap between historical epistemology and the philosophy of science.

\section{PART II}

\section{CASE-STUDIES}

How can we account for what is named by the appellation 'falsafa' in contemplation of the locked and suspended philosophical possibilities that remain concealed within the labyrinthine folds of its arrested intellectual histories? We reflect in this sense on the horizons of the renewal of the impetus of philosophical thinking in relation to the history of ideas in Islam, which surpass the limitations of academic assignments, in view of genuinely desiring the unfolding of original

\footnotetext{
${ }^{6}$ Avicennism (al-Sīnawīyya) constitutes the legacy of Ibn Sīnā (Avicenna) in philosophy and science.
} 
thought that is re-collective, de-structuring, and re-constructive in its modes of revealing the gravity of critically rethinking the inherited conventional methodologies.

In view of this thought-provoking call for thinking, we may tangentially appeal to foundational, classical traditions that had a deep impact on philosophizing in Islam, and exercised a profound influence on European scholarship in both the mediaeval and Renaissance epoch. For the sake of undertaking pathways that may inspire this endeavor, we will now turn to the scenes of instruction within the legacies of two groundbreaking eleventh century polymaths: Ibn Sīnā (Avicenna) and Ibn al-Haytham (Alhazen). Both luminaries offer pointers and directives that may partly assist us in reformulating some of the essential classical questions in ontology and epistemology, respectively in relation to reflections on the questions of being and perception. This line of inquiry presents us with selected philosophical pathways amongst many, which may potentially facilitate the founding of new modes of rethinking falsafa, as it is inspired by the intellectual history in Islam, and in a manner that is oriented by lived aspirations in the unfurling of original thinking.

\section{IBN SİNĀ'S ONTOLOGY}

Turning our gaze toward the ontological question concerning being, we reflect on Ibn Sīnā's philosophical legacy that offers us a concretized intellectual context to investigate the impetus of metaphysics in the history of ideas in Islam. Ibn Sinnā's ontology constituted one of the most influential legacies of falsafa in the intellectual history of Islamic civilization. This foundational tradition presents us with fundamental ontological notions that can be effectively assessed through dialectical and critical engagements with Heidegger's thought. The focus on Ibn Sīnā's ontology may also assist us in initiating a potentially critical dialogue revolving around Heideggerian notions that interrogated the rudiments of classical metaphysical thinking.

Ibn Sīnā's thinking not only had an impact on Thomism and Scotism, but was also widely assimilated within European mediaeval and Renaissance scholarship. Any philosophical inquiry about the continuance of classical Greek traditions in philosophy within mediaeval schools cannot be complete and probingly thorough unless it takes into account the transmitted contributions of the principal philosophers of mediaeval Islamic civilization in general, and of Avicennism in particular. It would not be an exaggeration to suggest that inquiries about Heidegger's critique of the history of metaphysics in reference to mediaeval philosophical doctrines would be incomplete if the principal conceptual bearings of Avicennism are not also critically examined, or if the prolongations of this longstanding tradition in classical ontology are not adequately investigated. Ibn Sīnā's legacy has its own European history, even if it is still considered by some philosophers, historians or theologians (principally in a non-Muslim milieu) as being the tradition of "the (oriental-Muslim) other" that has been veiled within that history. Ibn Sīnā's metaphysics belongs to the history of classical ontology that has been interrogated by Heidegger, even though Avicennism was not explicitly examined in detail within the Heideggerian legacy. 
I do not imply in this context that Heidegger was not aware of the assimilation of Ibn Sīnā's tradition within the European Latin scholarly circles. However, he might not have fully acknowledged the extent of the influence that has been exercised by Avicennism in that intellectual historical-cultural milieu. It might have been the case that Heidegger implicitly assumed that the entailments of Ibn Sinnā's metaphysics unquestionably belong to classical ontology, or he did not believe that Avicennism was integral to what he grasped as being the history of (Western) metaphysics.

The effort in reflecting on the fundamental notions of Ibn Sīnā's ontology, from the standpoint of critically thinking about the entailments of Heidegger's critique of the history of metaphysics, constitutes an ontological inquiry that is akin, in many aspects, to Heideggerian investigations that have been conducted on classical ontology, including studies on mediaeval European scholars of the caliber of St. Thomas Aquinas, Duns Scotus, Francisco Suárez, or Meister Eckhart. Such ontological inquiry would be principally focused on Ibn Sīnā's account of being (al-wujūd) in terms of contingency (al-imkān) and necessity (al$w u j \bar{u} b$ ), and in relation to the question concerning the distinction and connection between essence (quiddity; al-māhiyya) and existence (al-wujūd). Additional ontological aspects of Ibn Sīnā's philosophy relate to his epistemology and his conception of the soul (al-nafs) and its cognitive faculties (El-Bizri, 2003), along with reflections on the logical, etymological and linguistic properties of his metaphysical thinking; this includes the consideration of the innovative conceptual elements in his metaphysics that surpassed many of the notions that were associated with the Aristotelian and Platonist traditions (El-Bizri, 2001, 2006a, 2008a). Taking this into account, the conceptual elements that may be derived from Heideggerian perspectives on scholasticism may well assist us dialectically in investigating the extent of the applicability of Heidegger's critique of metaphysics across a variety of classical ontological traditions (including Avicennism), while furthermore opening up pathways to rethinking some of the principal notions of Ibn Sīnā's ontology in terms of relevant contemporary topics of philosophical debate. However, one must proceed in this context with caution given that our grasp of both thinkers (Ibn Sinnā, and Heidegger) is still faced with epistemic and doctrinal difficulties, in addition to variegated querelles d'écoles that surround their legacies.

From a Heideggerian viewpoint, philosophy is in essence an inquiry into being (Die Philosophie ist das Fragen nach dem Sein), and a reflection about the withdrawal of the meaning, truth and place of being (Sein) from thought. Thinking finds its possibilities in displacing the histories of thought, and the epochs that were grounded on them, in the great comings and goings of the foundational seasons in philosophy. The history of metaphysics and classical ontology is said to be a history of the oblivion of the ontological difference between being and beings and its abandonment in thought, which is closely connected to the unfolding of the essence of technology that is not strictly technological, but is essentially a mode of en-framing ( $\mathrm{Ge}$-Stell) beings in their being, and positing them as standing-reserve (Bestand). This forgetfulness of being is a mark of the self-persecuting character of the beingness of Dasein, namely, as that being who inquires about its being-inthe-world, and lets being reveal itself (Dasein conceived herein as: être-là, or être- 
le-là; Beaufret, 1985; El-Bizri, 2006b, 2006c). The history of philosophy is seen from this perspective as a grand drama of decline despite the heights of our technological age, which in its powerful rationalities, stands at what some picture as being the limits of the closure of metaphysics, its last frontiers, as the end of philosophy!

Heidegger reflected on the question of being (Seinsfrage) in his investigation of the basic problems of phenomenology in the summer lecture course of 1927 in Marburg (not published until 1975), which complemented the thesis of his major opus, Sein und Zeit (published in 1927, yet completed in 1926). Heidegger partly mediated the development of his own fundamental ontology by way of analyzing some of the principal theses of scholasticism regarding the constitution of the being of a being in relation to the classical controversy over the distinction and connection between essentia and existentia. It is well documented in his meditations on this question (in Die Grundprobleme der Phänomenologie) that the initial conceptual foundations of this ontological tradition were laid down by Avicenna [Ibn Sīnā] (Heidegger, 1975, p. 113).

The focus on Ibn Sinna's ontology can well be mediated by the manner he addresses the question of being (mas'alat al-wujūd) and the reflection on the internal dialectics that modulate his conception of the ontological bearings of the modalities of necessity and contingency with regard to the relationships between essence and existence, and the determination of the ontological difference between beings and the being of beings. This is the case even though the distinction between essence and existence is hinted at with ambivalence in the Aristotelian tradition in terms of thinking about what is intended from the saying, 'tode t $i$ ' (the 'thisness' of a present extant thing, or what in Scotism is designated in Latin as, 'haecceitas', namely, 'singularity in identity'), in contrast with the vague and hard to apprehend expression, 'to ti én einai' ('what it was for something to be the thing it is'). And yet, what is aimed at by these utterances, along with the Aristotelian categories, all refer back to the sustaining and leading fundamental meaning of 'ousia' ('substance'), which is always said alongside the various meanings of 'being' (Metaphysics, Books Theta and Zeta; Aristotle, 1924). Consequently, the ontological question concerning the meaning of being becomes a metaphysical interrogation about the notion of substance.

Heidegger suggests furthermore that Ibn Sīnā's distinction between essence and existence underlies the Kantian thesis about being (Kritik der reinen Vernunft: Critique of Pure Reason; Kant, 1929, A598-B626):

Being is obviously not a real predicate; that is, it is not a concept of something which could be added to the concept of a thing; it is merely the positing of a thing, or of certain determinations as existing in-themselves. Logically, it is the copula of a judgment.

This thesis is noted in the context of speculating about the impossibility of having an ontological proof in terms of reflecting on the transcendental dialectical inferences of pure reason. Based on this, realitas meant essentia and it constituted an ontological problem besides the metaphysical reflections on the meaning of essentia/subtantia. So, how does 'reality' and 'existence'belong to a being, let alone their ontological interconnection defined? Moreover, how can the 
distinction between essence and existence be interpreted in terms of the ontological difference between beings and being? According to Heidegger, the distinction between essentia and existentia does not correspond with the ontological difference between beings and being. Rather, it belongs to one side or the other of this binary bifurcation, namely, by positing primordial essence as an opposite counterpart of primordial existence. ${ }^{7}$

The problem of the distinctio and compositio between the essentia of a being and its existentia lies at the roots of the Kantian thesis about being (Heidegger, 1975, pp. 109-110). This can be articulated in terms of the following scholastic disjunctive binaries: ens infinitum vs. ens finitum; ens increatum vs. ens creatum; ens necessarium vs. ens contingens; ens per essentiam vs. ens per participationem; actus purus vs. ens potentiale; ens a se vs. ens ab alio; etc. ${ }^{8}$ The ens perfectissimum is: ens a se, ens infinitum, ens increatum, ens necessarium, ens per essentiam, actus purus. These notions offer Latin renditions of what Ibn Sinnā noted with regard to wājib al-wujūd bi-dhātihi and wäjib al-wujūd bi-ghayrihi, namely, by respectively differentiating (in ontological terms): Necessary-Beingdue-to-Its-Self from necessary-being-due-to-something-other-than-itself qua contingent-being-in-itself (Ibn Sīnā, 1874, pp. 262-3; 1960, p. 65; 1975, pp. 36-9, 43-7, 350-5; 1985, pp. 255, 261-5, 272-5, 283-5; El-Bizri, 2006a, 2008a). Necessary-Being-due-to-Its-Self is without quiddity and definition or description, and Its essence is being. The Necessary Existent due to Its-Self as Necessary Being qua Necessary Existence/Existing is Pure Being. All that can be uttered about Necessary Being is 'il y $a$ ' (Levinas, 1979, pp. 24-30), ' 'es gibt sein', 'there is', 'hunālika' ...'huwa'...

There is a manifold of dialectical dynamics that surround the meditations on wäjib al-wujūd per se: The Necessary-Existent is a determinate onto-theological being or existent that moves from pure being to determinateness in being. To evoke a Hegelian parlance we would say that pure being is sublated into determinate being, moving from being-itself to being-within-itself as being-foritself and being-for-other. This describes the double movement of emanating otherness from sameness and then re-attracting otherness to sameness. Despite investigating being qua being, an onto-theological turn is already attested with Aristotle's conception of metaphysics as theology, albeit, a new foundational phase in metaphysical thinking arises with the way Ibn Sīnā systemically conferred autonomy to ontology from the determinants of theology in reflecting on the question of being.

Ibn Sīnā's reflections on the relationship between essence and existence, based on the context of his account of the question of being, in terms of the modalities of necessity and contingency, found its highest consummation in Hegel's essentialism in the logical unfolding of Begriff (Wissenschaft der Logik; Hegel,

7 In the Islamic context, and in the historical reinterpretations of Ibn Sīnā's metaphysics, Suhrawardī (fl. $12^{\text {th }}$ cent.) argued in favor of the primacy of essence over existence, while Mullā Sadrā (fl. $17^{\text {th }}$ cent.) affirmed the primacy of existence over essence.

${ }^{8}$ The distinction between essence and existence, founded ontologically by Ibn Sīnā, becomes: a distinctio realis in Thomism; a distinctio formalis or modalis in Scotism; and a distinctio rationis with Suárez.

${ }^{9}$ We reflect here on the onto-theological implications of Levinas' critical response to Heidegger in terms of thinking about the hypostasis of l'exister sans existant (existing without existent). 
1969) ${ }^{10}$ and prior to the associated Kantian thesis that being is not a real predicate, as Heidegger proclaimed (Heidegger, 1975). The matter to be thought is how being is the indeterminate immediate universal that is the most abstract and simple self-evidence in presencing? This echoes the Kantian proposition that perception is the sole character of actuality, as Kant held in the context of assessing the postulates of empirical thought in his Kritik der reinen Vernunft (Critique of Pure Reason; Kant, 1929, A225-B273). Perception corresponds in this context to the disclosure of extant beings in perceptual acts. Hence, extant actual existents are perceived beings which are uncovered and disclosed in apperception through the inner-worldly phenomenal fields of perception.

\section{TRANSITION}

An insight into the line of thinking that may have also converged seeing with knowing can be detected in comparative terms by contemplating the meaning that is aimed at in the first proposition that opens Aristotle's Metaphysics, namely, "pantes anthrōpoi tou eidenai oregontai phusei" (Metaphysics; Aristotle, 1924, A, 980a 21). This line is customarily translated as, "All humans by nature desire to know". However, here is an alternative polemical reading proposed by Heidegger: "Im Sein des Menschen liegt wesenhaft die Sorge des Sehens" ("The care for seeing is essential to the being of the human being"; Heidegger, 1953, section 36). Herein, eidenai (to know, to see) is understood as being linked to eidos (outward appearance, look) insofar that the latter is construed as being the visible form of something. Knowing is transmuted into an act of seeing, whereby horan (sight) brings about knowledge of things more efficiently than all the other senses, and is hence irreducible to, the order of mere sense perception. The correspondence between knowledge and vision is perhaps attested in the manner in which Plato reinforced the cognitive character of theória over that of epistēme , whereby vision shows rather than tells. In addition, and as noted by Aristotle, horan highlights the differences between things (Metaphysics; Aristotle, 1924, A, 980a 25). Hence, it may be seen as being akin to the etymological root of the word, 'theoria', whereby the Greek terms 'thea' ('spectacle') and 'horao'' ('to see', 'to look') are brought together to determine the expression, 'theōria', which names a concept that refers to the act of seeing a spectacle, or looking at a view (McNeill, 1999, p. 174); the care for seeing intersects with the desire to know. Both find their roots in curiosity and in the modern advent of Die Zeit des Weltbildes (The time of the world-picture, or the apprehension of the world as a picture), wherein theōria becomes a representational mode of seeing with the human subject turning into the grounding Archimedean vantage point (McNeill, 1999, p. 221). This mode of addressing the question of being pulls thought toward reflections on the ontological determinants of perception.

\section{IBN AL-HAYTHAM'S PHENOMENOLOGY OF PERCEPTION}

\footnotetext{
${ }^{10}$ In Hegelian essentialism, being is simply the becoming of essence, while the becoming of being is a transition from being to essence.
} 
Although numerous studies have been conducted on the Optics (in Arabic: Kitāb al-manāzir; in Latin: De Aspectibus or Perspectivae) of al-Hasan Ibn al-Haytham (Alhazen, d. ca. 1041 CE; Ibn al-Haytham, 1972, 1983, 1989, 2001, 2002), and on its reception, assimilation and maturation within the perspectivae traditions in the history of science and art (Kemp, 1978, pp. 134-61; 1984, 1989; Lindberg, 1971, pp. 66-83; 1997, pp. 355-68), ambiguities still do hitherto surround the epistemological and ontological entailments of his theory of visual perception (ElBizri, 2005). Ibn al-Haytham's thinking speaks to us in an effective manner that is relevant in its attuned bearings to the thrust of phenomenological theories of perception, and their connection with the fundamental questions of ontology and epistemology.

Ibn al-Haytham offered an experiential analysis of how the manifestation of a thing in its plenitude through its visible aspects, which are detected in a continuum of manifold appearances, occurs by way of contemplation and bodily spatialtemporal displacement. Vision manifests the fullness of the volumetric massing of a thing as a constituted unified structure through the partial givenness of its apparent aspects in successions of continuous perceptions. This state of affair is illustrated by way of multiple perspectives, such that a thing is never seen in its entirety instantaneously and immediately, since the appearance of some of its sides entail that its remaining aspects are unseen. Hence, a partial disclosure of an opaque object in vision is always associated with the concealment of some of its surfaces. In visual perception, a visible object that is given through direct vision and immediate intuition reveals some of its surfaces or sides while its remaining aspects are veiled. A distinction is posited here between authentic qua proper appearances, namely, those which relate to a concrete act of seeing where the sides of the visible object are perceived in immediate intuition and direct vision, and inauthentic qua imagined appearances, namely, those which designate the imaginary surplus that accompanies the authentic appearances in the constitutive perception of the object of vision in its imagined totality. So, the full silhouette of a thing is constituted by its spatial-temporal bodily displacement ${ }^{11}$ and the essential unity between its authentic and inauthentic appearances. Hence, perspective is essentially a phenomenon of the mystery of spatial depth, which demarcates my situation in the world as being distinct from other perceivers, yet, it is also through spatial depth and temporal horizons that my relations with other perceivers and things are opened up.

The object of vision appears as a constant presence despite its optical variations in natural perspective and immediate intuition. Seeing does partly let things self-show themselves as they are, for what appears in the spectacle is led back to an order of familiarity, and, as Ibn al-Haytham showed, seeing is a mode of recognition, discernment, and comparative measure (al-ma'rifa wa-al-tamyizz wa-al-qiy $\bar{a} s)^{12}$ that allows what appears to self-show itself as it is given in its own

\footnotetext{
${ }^{11}$ This refers to the movement of the perceiver around the object of vision and/or the movement of the object of vision itself in such a way that its sides are revealed in succession to the observer.

${ }^{12}$ Ibn al-Haytham offered a physiological-neurological-psychological analysis of visual perception that went beyond the geometrical-physical explication in optics of the introduction of light rays into the eyes. Based on Ibn al-Haytham's experimental explanations (which rested on mathematics, physics, anatomy, and a series of experiential tests), only light qua light and color
} 
apparition in presencing. However, the semblance of constancy in presence is not guaranteed after the lapsing of a considerable period of time, given that things are subject to becoming and change (al-taghayyur).

Space-time, depth and place, as well as the corporeal engagement of the observer within the spectacle, all ground perception and its veridical potentials. It is through movement that the partial self-givenness of the formal reality of what is seen is affirmed in its wholeness. Perceptual acts are affirmed and corrected by other complementary verifying perceptions, whereby judgments resulting from certain errors in vision get rectified by way of additional verified data that rest on the acuity and sensitivity of vision itself, rather than doing away with the epistemic possibilities that this powerful perceptual capacity offers to cognition. ${ }^{13}$ Investigating the veridical conditions of vision in the science of optics was pivotal in Ibn al-Haytham's endeavor to mathematize the notions of physics (El-Bizri, 2007a, 2008c), and to establish the foundations of scientific experimentation (al$i$ 'tiba $\bar{a}$ ) and controlled testing, as they were grounded on the accurate registering of repeated observational data and geometrical modeling in determining the procedures of verification, demonstration, and proof. The precision of Ibn alHaytham's experiments was remarkable to the level that most of his tests, with their corresponding scientific instruments and designed experimental installations, were accurately reconstructed and reenacted about three centuries later by Kamāl al-Dīn al-Fārisī, as described in the latter's Tanqīh al-manāzir (The Recension of [Ibn al-Haytham's] Optics), and resulted in the reconfirmation of most of Ibn alHaytham's observations and data (al-Fārisī, 1928).

Following phenomenological directives, we note that something lets itself be brought to light or brightness in its appearing, and self-shows itself from itself, in that very condition of being lit and visible to a presencing observer. This event describes the unfurling of what may be referred to in Greek as, "apophainesthai ta phainomena", namely, "what shows itself from itself, just as it shows itself from itself". It is ultimately a translation of the maxim that animates phenomenology: "zu den Sachen selbst" ("to the things themselves"). And phenomenology is conceived here as being a fundamental ontology (Fundamentalontologie) that elucidates the question of being (Seinsfrage) by way of a hermeneutic and eidetic reflection on what is pointed out by the appellations, 'phaino',, (bringing beings to light or brightness), 'phainesthai' (showing itself from itself), and 'phainomenon' (what self-shows itself from itself). In other words, a phenomenon becomes

qua color constitute pure sensations, while seeing (vision) consists ultimately of complex physiological-neurological-psychological processes (El-Bizri, 2005; 2009).

${ }^{13}$ It is perhaps the case that the stationary gaze of Descartes on objects of vision might have led him to distrust the veridical conditions of sense perception as delineated in his Meditationes de Prima Philosophiae [Meditation on First Philosophy] (Descartes, 1993). It is worth stating herein that Ibn al-Haytham's account of the normal conditions of sight involve the following parameters: 1- The viewed object must be bright; 2- the distance between the object and the eye should be optimal (not too close and not too far); 3- the object should be in a plane with the eye; 4-the body of the object should have a proper volume; 5-if the body is transparent it should still allow for the trapping of some light rays; 6- a completely transparent body that does not trap any light rays is virtually invisible; 7- the distance between the viewer and the object of vision should comprise a transparent space; 8-the viewer should have sufficient time to view the object of vision; 9- the eye should be healthy; 10- the eye should be able to concentrate on the object vision (Ibn al-Haytham, 1983 and 1989, sections I.2 [1-26], I.8 [1-11]; El-Bizri, 2005). 
indicative of itself, and already presupposes a perceiver, whereby appearance does not conceal the essence of a thing as much as it reveals it in presencing, if not even by letting essence become self-shown as an apparition (Heidegger, 1953, section 7; Sartre, 1943, pp. 11-6).

The thrust of Ibn al-Haytham's theory of visual perception implicitly points to the possibilities of grasping optics, not merely as a scientific discipline that inquires about the conditions of sight and light in terms of an epistemology of photosensitive surfaces, but more as an eidetic inquiry about the constitution of forms in their essential ordering of geometric structures that is grounded on experiential and experimental verifications.

Vision is a mode of de-distancing that brings things that are not at hand nearer from their remoteness, and renders beings accessible even from afar. Linear perspective (perspectivae artificialis), and its pictorial order, does demarcate a distance between the eye of the observer and the objects of vision. Nonetheless, it de-distances beings in sight by assimilating the spectacle in the form of a picture. However, the distances or intervals that are cleared by vision, and accordingly brought into nearness in de-distancing, are not objective or measurable as such. Rather, they are existentially estimated in the very circumspect act of seeing as a spatial mode of encountering beings in de-distancing. In this context, Ibn alHaytham affirmed experimentally the visibility of spatial depth (Kitāb al-manāzir, II.3 [67-126]; Ibn al-Haytham, 1983, 1989) in contrast with the eighteenth century immaterialist thesis of Berkeley. ${ }^{14}$ After all, Berkeley believed that the distance from the eye to a given object of vision, as spatial depth, cannot be immediately perceived, but only suggested by mental cues offered to vision. Berkeley argued that sight does not show or in any way inform us that the visual object, which we immediately perceive, exists at a distance, given that objects produce twodimensional projections on the retina. As a consequence, there cannot be an immediate vision of space or three-dimensionality. Furthermore, spatial depth cannot be perceived, but is simply experienced, and so is the case with the estimation of the size of objects at a remote distance. Relying on the convergence of the eyes in judging the cues of the apparent size of a visible object, Berkeley, following the classical mathematicians (mainly Euclidean and Ptolemaic) who were critically interrogated by Ibn al-Haytham on this question, evokes the angle of vision as the principal estimative determinant.

The philosophical thrust of the affirmation of the visibility of depth by Ibn alHaytham is best elucidated in Merleau-Ponty's phenomenological analysis of the perception of space (Merleau-Ponty, 1945, pp. 294-309; El-Bizri, 2004). Based on our experiential situation in the world, we are not granted the simultaneous immediacy of seeing depth from our perspective, as well as seeing it in profile from the position of a viewer who looks at it laterally. However, this does not readily reduce the primacy of depth (profondeur) into simply being a dimension like breadth (largeur), given that depth is the most existential of all the dimensions, since it intrinsically belongs to our personal perspective that offers a

\footnotetext{
${ }^{14}$ Refer to Berkeley's views in: sections 2-28, 41-51 of An Essay towards a New Theory of Vision (1709); sections 43-44 of A Treatise Concerning the Principles of Human Knowledge (1710); the first dialogue in Three Dialogues between Hylas and Philonous (1713), along with remarks in The Theory of Vision Vindicated and Explained (1733); (Berkeley, 1948-1957; 1965).
} 
self-openness to the world and onto an inter-subjective worldly otherness. Being the ground of our perspective on things, depth furnishes us with a space of openness to communicate with others by way of merging the horizons of our fields of vision and sensory perception, along with the associated exchange of signifiers that rest on this lived inter-subjective experience of our being-in-theworld (In-der-Welt-sein; être-dans-le-monde). Depth is ultimately the dimension by which things appear as enveloping one another rather than being juxtaposed. Unlike mathematical representations, depth highlights the manner in which reality impinges on and confronts us with a sense of mystery in its eventful presentations that call for thinking about the place of being, truth and meaning.

Based on this introductory inquiry, and upon other complementary studies that were highlighted in the accompanying annotations, it is hoped that novel pathways for rethinking Islamic intellectual history, from the standpoint of contemporary philosophical debates, can indeed be undertaken in view of renewing the impetus of philosophizing in relation to Islam.

\section{ACKNOWLEDGEMENTS}

I thank Bo Mou, the Editor of Comparative Philosophy, and the three anonymous referees for their helpful comments which assisted me in refining this paper.

\section{REFERENCES}

Aristotle (1924), Metaphysics, David Ross (ed.) (Oxford: Oxford University Press).

Beaufret, Jean (1985), Dialogue avec Heidegger, Vol. 4: Le chemin de Heidegger [Dialogue with Heidegger, Vol. 4: Heidegger's Pathway] (Paris: Editions de Minuit).

Berkeley, George (1965), Berkeley's Philosophical Writings, David M. Armstrong (ed.) (New York: Macmillan Publishing Company).

----(1948-57), The Works of George Berkeley, Bishop of Cloyne, Arthur Aston Luce and Thomas Edmund Jessop (eds.), 9 vols (London: Thomas Nelson \& Sons Ltd.).

Descartes, René (1993), Meditationes de prima philosophia (Méditations Métaphysiques) [Metaphysical Meditations], trans. (Latin into French) Michelle Beyssade (Paris: Garnier-Flammarion).

El-Bizri, Nader (2000), The Phenomenological Quest between Avicenna and Heidegger (Binghamton, NY: Global Publications, SUNY at Binghamton).

---- (2001), “Avicenna and Essentialism", Review of Metaphysics 54: 753-78.

---- (2003), "Avicenna's De Anima between Aristotle and Husserl”, in AnnaTeresa Tymieniecka (ed.), The Passions of the Soul in the Metamorphosis of Becoming (Dordrecht: Kluwer Academic Publishers), pp. 67-89.

----(2004), "La perception de la profondeur: Alhazen, Berkeley et MerleauPonty" [The Perception of Depth: Alhazen, Berkeley and Merleau-Ponty], Oriens-Occidens: sciences, mathématiques et philosophie de l'antiquité à 
l'âge classique. Cahiers du centre d'histoire des sciences et des philosophies arabes et médiévales, CNRS 5: 171-84.

---- (2005), “A Philosophical Perspective on Alhazen's Optics", Arabic Sciences and Philosophy 15: 189-218.

----(2006a), "Being and Necessity: A Phenomenological Investigation of Avicenna's Metaphysics and Cosmology", in Anna-Teresa Tymieniecka (ed.), Islamic Philosophy and Occidental Phenomenology on the Perennial Issue of Microcosm and Macrocosm (Dordrecht: Springer), pp. 243-61.

---- (2006b), "Being-towards-death: On Martyrdom and Islam", Cristianismo nella storia 27: 249-79.

---- (2006c), “Uneasy Meditations Following Levinas", Studia Phaenomenologica 6: 293-315.

---- (2007a), "In Defence of the Sovereignty of Philosophy: al-Baghdādī's Critique of Ibn al-Haytham's Geometrisation of Place", Arabic Sciences and Philosophy 17: 57-80.

---- (2007b), "Imagination and Architectural Representations", in Marco Frascari, Jonathan Hale, Bradley Starkey (eds), From Models to Drawings: Imagination and Representation in Architecture (London: Routledge), pp. 34-42.

---- (2008a), "God: essence and attributes", in Timothy Winter (ed.), The Cambridge Companion to Classical Islamic Theology (Cambridge: Cambridge University Press), pp. 121-40.

----(2008b), "Hermeneutics and Tradition: Re-gathering the Epistles of the Brethren of Purity", in Sami Erdem (ed.), Islam ve Klasik (Istanbul: Bilim ve Sanat Vakfi), pp. 339-60.

----(2008c), "Le problème de l'espace: approches optique, géométrique et phénoménologique" [The Problem of Space: Optical, Geometrical and Phenomenological Approaches], in Graziella Federici Vescovini and Orsola Rignani (eds), Oggetto e spazio. Fenomenologia dell'oggetto, forma e cosa dai secoli XIII-XIV ai post-cartesiani (Firenze: Edizioni del Galluzzo), pp. 5970 .

---- (2009), "Ibn al-Haytham et le problème de la couleur" [Ibn al-Haytham and the Problem of Color], Oriens-Occidens sciences, mathématiques et philosophie de l'antiquité à l'âge classique. Cahiers du centre d'histoire des sciences et des philosophies arabes et médiévales, CNRS 7: 201-26.

----(2010), "Creative inspirations or intellectual impasses? Reflections on relationships between architecture and the humanities", in Soumyen Bandyopadhyay, Jane Lomholt, Nicholas Temple and Renée Tobe (eds), The Humanities in Architectural Design: A Contemporary and Historical Perspective (London: Routledge), pp. 123-35.

al-Fārisī, Kamāl al-Dīn (1928), Tanqīh al-manāzir [Recension of (Ibn alHaytham's) Optics], 2 vols (Hyderabad: Osmania Publications Bureau).

Hegel, G. W. F. (1969), Wissenschaft der Logik (The Science of Logic), translated by A.V. Miller (London: George Allen \& Unwin).

Heidegger, Martin (1953), Sein und Zeit [Being and Time] (Tübingen: Max Niemeyer Verlag).

----(1975), Die Grundprobleme der Phänomenologie [Basic Problems of Phenomenology] (Frankfurt am Main: Vittorio Klostermann). 
Ibn al-Haytham (1972), Opticae thesaurus Alhazeni, Friedrich Risner (ed.); reprint from the 1572 edition (New York: Johnson Reprint Corporation).

---- (1983), Kitāb al-manāzir [Book of Optics], Vols I-III, ed. A. I. Sabra (Kuwait).

---- (1989), The Optics of Ibn al-Haytham, Books I-III, On Direct Vision, trans. A. I. Sabra, 2 vols. (London: Warburg Institute).

---- (2002), Kitāb al-manāzir [Book of Optics], Vols IV-V, A. I. Sabra (ed.) (Kuwait).

---- (2001), Alhacen's Theory of Visual Perception, trans. Albert Mark Smith (ed.) (Philadelphia: American Philosophical Society).

Ibn Sīnā (1874), Kitāb al-Hidāya [Book of Guidance], ed. Muhammad 'Abdu (ed.) (Cairo).

---- (1975), Kitāb al-Shifā', al-ilāhiyyāt [Book of Healing, Metaphysics] George C. Anawati, Ibrahim Madkour, Said Zayed (eds.) (Cairo).

----(1985), Kitāb al-Najāt, al-ilāhiyyāt [Book of Deliverance, Metaphysics], Majid Fakhry (ed.) (Beirut).

---- (1960) al-Ishārāt wa-al-tanbīhāt [Pointers and Directives], Vol. III, Sulayman Dunya (ed.) (Cairo).

Kant, Immanuel (1929), Kritik der Reinen Vernunft (Critique of Pure Reason), trans. Norman Kemp Smith (New York: Macmillan \& Co., Ltd.)

Kemp, Martin (1978), "Science, Non-Science, and Nonsense: Brunelleschi's Perspective", Art History 1: 134-61.

----(1984), Geometrical Perspective from Brunelleschi to Desargues (Oxford: Oxford University Press).

----(1990), The Science of Art: Optical Themes in Western Art from Brunelleschi to Seurat (New Haven: Yale University Press).

Levinas, Emmanuel (1979), Le temps et l'autre [Time and the Other] (Paris: Presses Universitaires de France).

Lindberg, David C. (1971), "Lines of Influence in the $13^{\text {th }}$ cent. Optics: Bacon, Witelo, and Pecham", Speculum 46: 66-83.

----(1997), "La réception occidentale de l'optique arabe" [The Occidental Reception of Arabic Optics], in Roshdi Rashed and Régis Morélon (eds), Histoire des sciences arabes, vol. II: Mathématiques et physique (Paris: Le Seuil), pp. 355-68.

McNeill, William (1999), The Glance of the Eye: Heidegger, Aristotle, and the Ends of History (Albany: State University of New York Press).

Merleau-Ponty, Maurice (1945), Phénoménologie de la perception [Phenomenology of Perception] (Paris: Gallimard).

Sartre, Jean-Paul (1943), L'être et le néant, essai d'ontologie phénoménologique [Being and Nothingness: An Essay in Phenomenological Ontology] (Paris: Gallimard).

Said, Edward (1978), Orientalism (New York: Pantheon Books, Random House). 